\title{
Effect of genotype and contrasting climate conditions on physical and chemical characteristics of soybean (G/ycine max L. Merrill)
}

\author{
Wpływ genotypu i kontrastujących warunków klimatycznych na cechy \\ fizykochemiczne nasion soi (Glycine max L. Merrill)
}

\section{Lech Boros $^{1 \oplus}$, Anna Wawer ${ }^{1}$, Magdalena Wiśniewska ${ }^{2 \oplus}$, Danuta Boros ${ }^{2 \oplus 凶}$}

\author{
${ }^{1}$ Department of Seed Science and Technology, Institute of Plant Breeding and Acclimatization - National \\ Research Institute, 05-870 Radzików. Poland \\ ${ }^{2}$ Laboratory of Quality Evaluation of Plant Materials, Institute of Plant Breeding and Acclimatization - National \\ Research Institute, 05-870 Radzików. Poland \\ $\triangle$ e-mail: d.boros@ihar.edu.pl
}

\begin{abstract}
Global warming has increased interest in growing soya in Poland. Variable weather conditions during the vegetation seasons, however, still make its cultivation potentially risky. In this study we wanted to assess how contrasting climate conditions influence on seed yield, 1000 seed weight and other important physical traits, as well as on contents of nutrients, dietary fibre constituents, trypsin inhibitor and phenolic components in nine soybean genotypes of different earliness. The field experiments were conducted in two consecutive vegetation seasons at Radzików, located in central Poland. Comprehensive seed characteristics of physical and chemical traits allowed to identify the best varieties for different end-uses, food or feed. A significant effect of variety and year of cultivation were observed for all evaluated traits. With the exception for the length of vegetation period, seed yield, seed coat and soluble non-starch polysaccharide content, significant interactions between variety and year of cultivation were found for the remaining traits. Weather conditions, such as very low precipitation with an average temperature above the multi-year average temperature in the month of July, when pod and seed is in full development, had a negative effect on all seed traits evaluated, regardless of variety earliness.
\end{abstract}

Key words: soybean, seed yield, cooking properties, nutrients, dietary fibre

Globalne ocieplenie klimatu spowodowało wzrost zainteresowania uprawą soi w Polsce. Zmienne warunki pogodowe w okresie wegetacji sprawiają jednak, że jej uprawa jest nadal potencjalnie ryzykowna. W niniejszych badaniach chciano ocenić, jak kontrastujące warunki klimatyczne wpływają na plon nasion, masę tysiąca nasion i inne ważne cechy fizyczne, a także na zawartość składników pokarmowych, składników błonnika pokarmowego, inhibitora trypsyny i związków fenolowych w dziewięciu genotypach soi o różnej wczesności. Doświadczenia polowe przeprowadzono w dwóch kolejnych sezonach wegetacyjnych w Radzikowie, położonym w centralnej Polsce. Kompleksowa charakterystyka nasion pod względem cech fizycznych i chemicznych pozwoliła na wytypowanie najlepszych odmian do różnych zastosowań końcowych, spożywczych lub paszowych. Stwierdzono istotny wpływ odmiany i roku uprawy dla wszystkich ocenianych cech. Z wyjątkiem długości okresu wegetacji, plonu nasion, okrywy nasiennej i zawartości rozpuszczalnych polisacharydów nieskrobiowych, dla pozostałych cech stwierdzono istotne interakcje między odmianą a rokiem uprawy. Warunki pogodowe, takie jak bardzo niskie opady przy średniej temperaturze powyżej średniej wieloletniej w miesiącu lipcu, kiedy strąki i nasiona są w pełni wykształcone, miały negatywny wpływ na wszystkie oceniane cechy nasion, niezależnie od wczesności odmiany.

Słowa kluczowe: soja, plon nasion, właściwości kulinarne, składniki odżywcze, włókno pokarmowe

\section{Introduction}

Soybean is the leading legume crop worldwide, and its production is steadily increasing, in line with the growing demand for plant proteins, essential for intensively growing animal production. According to the FAO latest data (FAOSTAT, 2020), in 2018, annual global production of soybeans was 349 million tonnes and was cultivated on the area of 125 million hectares.
In EU, soybean was grown on nearly 1 million hectares, with the annual production 2,9 million tonnes. In Poland, soybean production is still very small (annually about 20 thousand hectares). It is assumed that the progressive global warming and the activities undertaken in the Protein Initiative Program, established in 2017, shell lead to a significant increase in its cultivation in the coming years (COBORU, 2020). Increasing 
soybean production is considered to be the best way to reduce import of genetically modified soybean meal (SBM) in Poland.

Soybean seeds are an excellent raw material for the food and feed industry. Dry seeds contain approximately $40 \%$ protein, $22 \%$ oil, $32 \%$ carbohydrates and lignin and 5\% ash (NRC, 2012). Among others, seeds contain also various bioactive compounds, like vitamins and phytoestroges (Banaszkiewicz, 2011; Medic et al. 2014; O'Bryan et al. 2014). However, phytoestrogens, the class of phenolic compounds, which in soybean are represented by isoflavones (daidzein, genistein), can cause reproductive disturbances in mammals (Wocławek-Potocka et al. 2005). The raw soybean seeds contain also several components, which diminish their nutritional value, among them protease inhibitors, active against trypsin and chymotrypsin, next lectins, phytates and allergens (Liener, 1994). Seeds of soybean are appreciable source of dietary fibre, a complex component that has beneficial effects in humans but is undesirable in large quantities in animal feed mixtures. A high intake of dietary fibre significantly lowers serum cholesterol level and blood pressure, prevents obesity, improves glucose tolerance, and has anti-inflammatory and anti-carcinogenic effect on digestive system (Scheppach et al. 2004, O’Bryan et al. 2014). Moreover, dietary fibre is recently receiving attention in animal feeding as a dietary component that can contribute to better gut health of the host (Jha et al. 2019). The relatively high oligosaccharide content of soybeans may play an important role in this effect. Seed yield and seed chemical composition are genetically controlled, however, they are known to be influenced by biotic and abiotic factors, such as fungal and viral infections, insect pests and weeds, maturity, growing season, geographic location, and agronomic practices (Vollmann et al. 2000; Medic et al. 2014; Bellaloui et al. 2015; Goyal et al. 2015; Assefa et al. 2019; Li et al. 2020). The seed chemical composition changes during soybean seed development (Saldivar et al. 2011), moreover depends on the seed node position along the main stem of plant (Huber et al. 2016).

Due to insufficient production, the EU countries cover $70 \%$ of their plant protein requirements by import. Breeding progress, economic and legal conditions in Poland and climatic changes favourable for thermophilic species should make soybean cultivation more profitable in a short time and increase its acreage together with other domestic legume species. The warming and lengthening of the growing season, observed for several years in our latitude, makes the farmers more and more interested in crop species, such as soybean.

In recent years, several soybean varieties developed by domestic and foreign breeding companies have been introduced into cultivation in Poland, but the physicochemical characteristics of the seeds in relation to culinary quality parameters and chemical composition as effected by climate changes has not been evaluated. Moreover, knowledge of certain physical properties of soybean seeds can be helpful not only in selecting the best varieties for consumption, but also in selecting varieties for feed purposes. Such information should be useful for breeders and all end-users in feed and food processing chain.

\section{Materials and Methods}

\section{Field Trial Design, Whether Conditions and Seed Yield}

Nine various genotypes of soybean (Glycine $\max ($ L.) Merrill) were used in this study. Three varieties and two breeding lines (Aldana, Augusta, Jutro, LP-1 and LP-2) were of Polish origin, two of Ukrainian (Mavka and Annushka) and one of Austrian (Merlin). Varieties Mavka and Merlin belong to semi-late earliness group, while the other varieties and breeding lines belong to very early and early group of earliness. The varieties, except for Jutro and Progress, are listed in the Common Catalogue (2020). The field trials were carried out over a period of two growing seasons (2013 and 2014), at the Institute of Plant Breeding and Acclimatisation-National Research Institute at Radzików, located in the central part of Poland $\left(52^{\circ} 13^{\prime} 38^{\prime \prime} \mathrm{N} 20^{\circ} 36^{\prime} 55^{\prime \prime} \mathrm{E}\right)$. Seeds of each variety were planted in four row plots of $10 \mathrm{~m}^{2}$ with density of 80 seeds $\cdot \mathrm{m}^{2}$, in four replicates, as a randomized complete block design. The basic elements of sustainable crop management were applied, that included seedbed preparation, fertilisation, sowing, rational chemical protection (selection of doses and adherence to deadlines for applications).

Weather conditions during field experiments were obtained from the meteorological station located at Radzików, together with those for the last 55 years (Figure 1a and Figure $1 b$ ).

The 2013 season was characterised by high average monthly temperatures, with the exception of the months of April and September compared to the long-term data. In contrast, temperatures in April, July and September of the 2014 growing season were higher than corresponding 


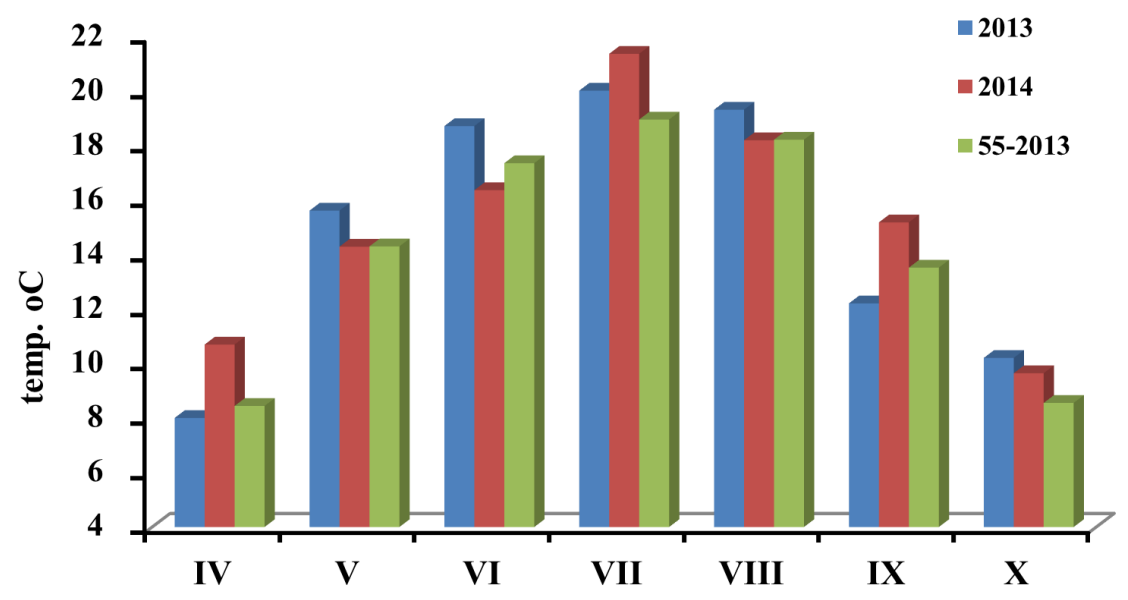

Figure 1a. Average monthly temperatures in two growing seasons in comparison to multi-year temperatures (1958-2013) for Radzików.

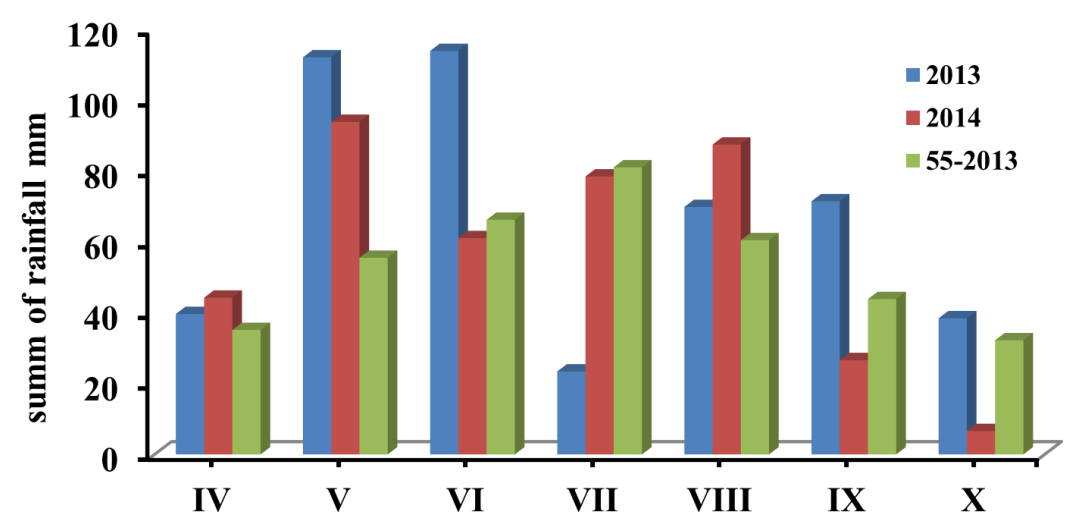

Figure 1b. Monthly precipitation in two growing seasons in comparison with precipitation in multi-year period (19582013) for Radzików

values in 2013 and long-term data (Fig.1 a.). Growing seasons in question differed significantly in their precipitation distribution (Fig.1b.) The season of 2013, with excessive precipitation in May and June, causing flooding, soil compaction, poorer nodulation and drought in the month of July had a significant impact on the quantity and quality of harvested soybean seeds. The 2014 growing season was characterised by a more even distribution of rainfall and a warm and dry autumn, thus favourable conditions for later maturing soybean varieties.

Harvested seeds from each plot were cleaned, weighed, and tested for moisture content. Reported yield was adjusted to $15 \%$ moisture content.

\section{Measurements of Seed Physical Properties}

Physical traits and chemical analyses were performed on laboratory seed samples, created by combining seeds of a given variety from four field plots and after well mixing an average sample was taken. Each analysis of physical and chemical traits was performed in triplicate.

Random selected 100 seed samples from each genotype were weighed using a digital electronic balance having an accuracy of $0.001 \mathrm{~g}$ and then recalculated to 1000 seed weight in grams. Bulk density was determined as the ratio between the mass and the volume of 100 soybean seeds. The bulk density was expressed in $\mathrm{kg}$ per hectolitre $\left(\mathrm{kg} \cdot \mathrm{hl}^{-1}\right)$

Percentage of seed coat was determined using 10 random seeds. The seeds were soaked in distilled water at $5^{\circ} \mathrm{C}$ for $12 \mathrm{~h}$. After that, the seed coat was easily separated from each seed using a preparation needle. The dehulled seeds and the seed coats were dried in oven at $105^{\circ} \mathrm{C}$ for $24 \mathrm{~h}$. After drying and cooling to ambient temperature, both parts 
of seeds were weighed separately and the seed coat percentage was calculated of the seed weight. The absorption of water was determined for the sample of 50 seeds of known mass, soaked in distilled water for 18 hours at a temperature of $25^{\circ} \mathrm{C}$. Hydration capacity $\left(\mathrm{g} \cdot \mathrm{seed}^{-1}\right)$ was recorded as gain in weight after 18 hours of soaking in distilled water. The swelling capacity per seed $\left(\mathrm{ml} \cdot\right.$ seed $\left.^{-1}\right)$ was determined as gain in volume after 18 hours of soaking in distilled water.

The cooking time was determined on Mattson Cooker, made according to the Jackson \& Varriano-Morston model, which was applied to assess the cooking time of soybean, common beans and peas seeds (Destro et al. 2013; Boros and Wawer, 2018; Wang et al. 2010). The cooking time was measured from the time the water was boiled until 20 of 25 pins of a specified weight had penetrated $80 \%$ of the seeds (CT $80 \%$ ).

\section{Measurements of Chemical Composition}

Prior to chemical analysis all seed samples were ground on a cyclone laboratory mill (Foss, CT 193 Cyclotec $^{\mathrm{TM}}$ ), to pass a $0.5 \mathrm{~mm}$ screen. Error of each chemical analysis did not exceed $3 \%$.

The contents of basic components: dry matter, crude protein, ash and available starch were analysed using standard procedures of AOAC (2010). A conversion factor 6,25 was used to estimate protein content from determined nitrogen content. Total lipids were determined by the gravimetric method, after extraction of the sample with a solution of chloroform, methanol and hydrochloric acid, mixed in proportions 60:40:1 (v/v/v), according to Marchello et al. (1971).

Determination of trypsin inhibitor activity (TIU) was performed using a BAPNA substrate, and the amount of p-nitroaniline released was measured spectrophotometrically at $410 \mathrm{~nm}$ (UV-1800 spectrophotometer, Beijing Rayleigh Analytical Instrument Corporation - BRAIC) according to the method of Kakade et al. (1974).

The amount of total phenolics (TPC) was determined according to the Folin-Ciocalteu procedure (Martinez-Villaluenga et al. 2009). Absorption at $765 \mathrm{~nm}$ was measured on UV-1800 spectrophotometer (BRAIC). The total phenolic content was expressed as gallic acid equivalents (GAE) in milligrams per gram dry matter. Condensed tannins content were determined by the vanillin $\mathrm{HCl}$ assay as described by Price et al. (1978). The absorption was measured at $500 \mathrm{~nm}$ on a UV-1800 spectrophotometer (BRAIC). Catechin was used as the standard for the calibration curve. Condensed tannin content was expressed as mg catechin equivalents (CE) per g sample (dry basis).

Total dietary fibre (TDF) was determined by an enzymatic-chemical method with the Uppsala procedure (Theander et al. 1995), increased by nondigestible oligosaccharides, which is in compliance with the European Food Safety Authority definition of TDF (EFSA, 2010). In this method TDF is calculated as the sum of nonstarch polysaccharides (NSP), oligosaccharides, uronic acids and Klason lignin (AOAC, 2010). The nonstarch polysaccharides (NSP), with its soluble (S-NSP) and insoluble (I-NSP) fractions, were analysed according to Englyst and Cummings (1984). After purifying from free sugars and available starch, the samples were fractioned into soluble and insoluble fractions by centrifugation (Eppendorf, Centrifuge 5702). The I-NSP fraction, in the pellet, underwent first dispersion of cellulose with $12 \mathrm{M}$ sulphuric acid $\left(30^{\circ} \mathrm{C}, 0.5 \mathrm{~h}\right)$, then hydrolysis into monosaccharides with $1 \mathrm{M}$ sulphuric acid $\left(100^{\circ} \mathrm{C}, 2 \mathrm{~h}\right)$. The ethanol precipitated S-NSP fraction were hydrolysed into monosaccharides with $1 \mathrm{M}$ sulphuric acid, the same as I-NSP. The released monosaccharides in both fractions, derivatized to alditol acetates, were quantified on a capillary column (30m length and $0.53 \mathrm{~mm}$ id; cat \#14049 from Restek Corporation, 110 Benner Circle, Bellefonte, USA) in a gas chromatograph (Clarus 500, Perkin-Elmer) equipped with an autosampler, a splitter injection port and a flame ionisation detector. Helium was used as a carrier gas. Temperature of the detector was $250^{\circ} \mathrm{C}$ and that of the injector $220^{\circ} \mathrm{C}$. The column oven program started at $190^{\circ} \mathrm{C}$ increasing by $5^{\circ} \mathrm{C} /$ min up to $215^{\circ} \mathrm{C}$ and holding this temperature for $5 \mathrm{~min}$. S-NSP and I-NSP were calculated as the sum of constituent sugars of each fraction and their values are presented as anhydrous sugars. A total NSP was calculated as a sum of both NSP fractions.

Raffinose family oligosaccharides (RFO) were determined by the method of Lahuta (2006). Oligosaccharides extracted with 50\% ethanol were derivatized with a mixture of trimethylsilyl imidazole and pyridine $(1: 1, \mathrm{v} / \mathrm{v})$. Trimethylsilyl derivatives of carbohydrates were separated on a capillary column (ZEBRON ZB-1, 15 m, 0.25 mm, packed with $0.1 \mu \mathrm{m}$ layer of $100 \%$ dimethylpolysiloxane) in gas chromatograph (AutoSystem XL, Perkin-Elmer). RFO were calculated as the sum of raffinose, stachyose and verbascose. Uronic acids (UA) analysed with the colorimetric method of Scott (1979), using 3.5-dimethylphenol, highly reactive to UA derivatives. UA were calculated 
by measuring the difference between absorbance at $400 \mathrm{~nm}$ and $450 \mathrm{~nm}$ on a UV-1800 spectrophotometer (BRAIC). The solution of D-galacturonic acids was used as a standard. Klason lignin was determined gravimetrically as the ash-free acid insoluble residue after two-step acid hydrolysis with $72 \%$ sulphuric acid $\left(30^{\circ} \mathrm{C}, 0.5 \mathrm{~h}\right)$ and $1 \mathrm{M}$ $\mathrm{H}_{2} \mathrm{SO}_{4}\left(100^{\circ} \mathrm{C}, 3 \mathrm{~h}\right)$ (Theander et al. 1995).

\section{Statistical Analysis}

The data were subjected to analysis of variance (ANOVA) by Tukey HSD test $(p=0.05)$ using Statgraphics 5.1 Software. The principal component analysis (PCA) were calculated for determining the relationship between different variable. The PCA results were graphically presented by the projection of the two principal components.

\section{Results and Discussion}

Analysis of variance, presented in Table 1, showed significant differences for all sources of variation (nine varieties, two growing seasons and 22 traits of physical and chemical characteristics). Predominant influence of the growing season was revealed for all evaluated traits. Except for length of vegetation period, seed yield, seed hull and soluble nonstarch polysaccharide content, a significant genotype $\mathrm{x}$ year interaction $(\mathrm{G} \times \mathrm{Y})$ was observed for the remaining traits. The significance of the interaction indicated differences in the response of the tested soybean genotypes to varying weather conditions, which affected

Table 1

Tabela 1

Analysis of variance (mean square and significance) of genotype and harvest year effects on agronomic traits, physical and chemical characteristics of soybean

Analiza wariancji (średni kwadrat i istotność) wpływu genotypu i roku zbioru na cechy agronomiczne, fizyczne i chemiczne soi

\begin{tabular}{|c|c|c|c|}
\hline \multirow{2}{*}{$\begin{array}{l}\text { Trait } \\
\text { and abbreviations }\end{array}$} & \multicolumn{3}{|c|}{ Mean squares } \\
\hline & Genotype (G) & Year $(Y)$ & $\mathrm{G} \times \mathrm{Y}$ \\
\hline$d f$ & 8 & 1 & 8 \\
\hline \multicolumn{4}{|c|}{ Agronomic traits and physical properties } \\
\hline Length of growing season (LGS) & $579.3 * *$ & $10976.7 * *$ & $29.4 \mathrm{~ns}$ \\
\hline Seed yield (SY) & $0.51 * *$ & $19.7 * *$ & $0.06 \mathrm{~ns}$ \\
\hline 1000 seed weight (TSW) & $1384.0^{* *}$ & $45014.7 * *$ & $137.2 * *$ \\
\hline Bulk density (BD) & $8.46^{* *}$ & $123.58 * *$ & $2.80 * *$ \\
\hline Seed hull (SH) & $1.52 * *$ & $53.25 * *$ & $0.06 \mathrm{~ns}$ \\
\hline Hydration capacity HC) & $0.0031 * *$ & $0.0824 * *$ & $0.0003 * *$ \\
\hline Swelling capacity (SC) & $0.0061 * *$ & $0.0996 * *$ & $0.0014 * *$ \\
\hline Cooking time $(\mathrm{CT})$ & $102.48 * *$ & $320.81 * *$ & $20.70 * *$ \\
\hline \multicolumn{4}{|c|}{ Seed components } \\
\hline Protein & $0.72 * *$ & $609.27 * *$ & $0.96^{* *}$ \\
\hline Lipids & $3.34 * *$ & $78.32 * *$ & $3.49 * *$ \\
\hline Ash & $0.33 * *$ & $7.14 * *$ & $0.03 * *$ \\
\hline Starch & $0.97 * *$ & $1.28 * *$ & $0.16^{* *}$ \\
\hline Trypsin inhibitor unit (TIU) & $121.29 * *$ & $730.26^{* *}$ & $31.26^{* *}$ \\
\hline Total phenolic components (TPC) & $0.14 * *$ & $0.84 * *$ & $0.03 * *$ \\
\hline Tannins (TA) & $0.0023 * *$ & $0.0337 * *$ & $0.0033 * *$ \\
\hline Nonstarch polysaccharides (NSP) & $0,90 * *$ & $9.72 * *$ & $0,65 * *$ \\
\hline Insoluble NSP (I-NSP) & $0.92 * *$ & $13.09 * *$ & $0.62 * *$ \\
\hline Soluble NSP (S-NSP) & $0.0041 *$ & $0.2516^{* *}$ & $0.0019 \mathrm{~ns}$ \\
\hline Raffinose family oligosaccharides (RFOs) & $0.33 * *$ & $20.29 * *$ & $0.93 * *$ \\
\hline Total uronic acids (TUA) & $0.14 * *$ & $3.57 * *$ & $0.04 * *$ \\
\hline Lignin & $0.50 * *$ & $2.00 * *$ & $0.28 * *$ \\
\hline Total dietary fibre (TDF) & $2.10 * *$ & $21.24 * *$ & $0.77 * *$ \\
\hline
\end{tabular}

$d f$ - degree of freedom; ** significant at $p<0.01 ; *$ significant at $p<0.05 ;:$ ns - not significant 
the physicochemical properties of seeds. In turn, the significant year effect on all traits indicated the sensitivity of varieties to environmental factors that prevailed in each year. However, in our study we found only a small contribution of the $G$ $\mathrm{x} Y$ interaction in the total variability of traits. Mourtzinis et al. (2018) and Assefa et al. (2019) reported that in the US about $70 \%$ of the yield variability of soybean was associated with environments defined as site-year effects.

\section{Effect of growing season on physicochemical characteristics}

Variable weather conditions during field experiments in two consecutive years had a significant effect on the values of determined soybean seed traits. The study showed, that a warm spring and a more even distribution of air temperatures and rainfall during the summer months of 2014 favoured soybean production in terms of yield, physical characteristics and chemical composition of the seed. In contrast, weather conditions in 2013, with high precipitation in May and June, little rainfall in July and relatively high air temperatures from the day of sowing in May to the end of August, had an adverse effect on all these traits (Tables 2-4). These unfavourable weather conditions primarily resulted in a shortened growing season of all soybean varieties (by 24.7 days on average), reduced seeds yield (by $1.05 \mathrm{t}$.ha), lower TSW (by $70.7 \mathrm{~g}$ ) and bulk density (by $3.7 \mathrm{~kg} \cdot \mathrm{hl}$ ) compared to seeds harvested the following year (Table 2). Seeds harvested in 2013 also had a higher proportion of hull (by almost 2\%), lower hydration (by $0.08 \mathrm{~g}$ ) and swelling (by $0.9 \mathrm{ml}$ ) capacity and required a shorter time for cooking (by nearly 5 minutes) than those origin from the 2014 growing season.

The shorter growing season lead to a drastic decrease in content of seed protein (by 8.2 percentage units), but an increase in lipids (by 3 percentage units), ash (by 0.9 percentage units), and to a lesser extent starch compared to seeds harvested in 2014 (Table 3). Among bioactive components, soybean seeds harvested in 2013 had significantly more trypsin inhibitor but fewer phenolic compounds, especially tannins (2.8 times less). Excessive soil moisture, due to high rainfall in the first two months of the 2013 growing season, may have probably partly contributed to lower seed yields as well as low protein content due to insufficient nodulation of the soybean and thus insufficient nitrogen fixation. Protein content under these weather conditions was exceptionally low, not previously recorded, and averaged $28.3 \%$, ranging from
27.2 to $29.2 \%$. The reverse situation was observed for lipids, whose average content of $27.4 \%$ was higher than that most commonly reported in the literature. For comparison, the protein content of 34 soybean varieties from post-registration varietal experiments conducted in 2019 and 2020 at ten COBORU experimental stations in Poland averaged $36.5 \%$ and $39.2 \%$, respectively, while fat content averaged $23.1 \%$ and $22.1 \%$, respectively (COBORU, 2021). It is worth noting that in the 2019 experiments, seeds of eight varieties from the late and very late maturity group and two varieties from the medium-early and medium-late maturity group could not be harvested from all locations due to persistent weather deterioration at the end of the growing season or frequent rainfall during the growing season, which for some varieties resulted in a lack of readiness for harvest (COBORU, 2021). The results of our study on the factors responsible for variability in yield, protein and fat content correspond to those of Vollmann et al. (2000). According to these authors, yield and protein content are most affected by weather conditions during the seed-filling period. High air temperature and moderate rainfall during this period favour high yielding and high accumulation of protein in soybean seeds.

The content of TDF and its components were also affected by climate conditions during the growing seasons (Table 4). Seeds of all varieties from the 2013 harvest had significantly more dietary fibre (by 1.5 percentage units) compared to seeds harvested in 2014, as a result of higher amounts of RFOs (by 1.5 percentage units), uronic acid and lignin by ( 0.5 percentage units in both cases). However, the content of total NSP in these seeds, including its insoluble fraction, was lower (by 1.0 and 1.2 percentage units, respectively) as in seeds originated from 2014. The TDF content of soybeans harvested in 2013 was $24.6 \%$, while in 2014 it was $23.1 \%$.

The distribution of temperature and precipitation during the growing seasons not deviating drastically from the multi-year data seems to be suitable for soybean cultivation in Poland. In such weather conditions, there is no risk of growing varieties with a longer growing season, which usually yield better. The yield of varieties under such conditions was relatively high, 3.5 tha on average, and the physical properties and chemical composition of seeds were comparable with the results most often cited recently in the literature (COBORU, 2021; Staniak et al. 2021). The higher content of raffinose family oligosaccharides (RFOs) and lignin found 
Table 2

Tabela 2

Agronomic and physical characteristics of nine soybean genotypes across two growing seasons.

Cechy agronomiczne i fizyczne dziewięciu genotypów soi w dwóch sezonach wegetacyjnych.

\begin{tabular}{|c|c|c|c|c|c|c|c|c|}
\hline Variety & $\begin{array}{l}\text { Length of growing } \\
\text { season (days) }\end{array}$ & $\begin{array}{l}\text { Seed yield } \\
(\mathrm{t} / \mathrm{ha})\end{array}$ & $\begin{array}{c}1000 \\
\text { seed } \\
\text { weight } \\
(\mathrm{g})\end{array}$ & $\begin{array}{c}\text { Bulk } \\
\text { density } \\
(\mathrm{kg} / \mathrm{hL})\end{array}$ & $\begin{array}{l}\text { Seed } \\
\text { hull } \\
(\%)\end{array}$ & $\begin{array}{c}\text { Hydration } \\
\text { capacity } \\
\left(\mathrm{g} / \text { seed }^{-1}\right)\end{array}$ & $\begin{array}{l}\text { Swelling capacity } \\
\left(\mathrm{mL} / \text { seed }^{-1}\right)\end{array}$ & $\begin{array}{c}\text { Cooking time } \\
(\min )\end{array}$ \\
\hline \multicolumn{9}{|c|}{ Growing season 2013} \\
\hline Aldana & 99.5 & 2.55 & 120.8 & 71.5 & 8.12 & 0.227 & 0.187 & 17.80 \\
\hline Annushka & 99.5 & 2.25 & 98.6 & 69.8 & 8.99 & 0.177 & 0.140 & 30.36 \\
\hline Augusta & 99.0 & 2.19 & 94.7 & 69.6 & 9.38 & 0.157 & 0.133 & 21.04 \\
\hline Jutro & 98.5 & 2.48 & 120.0 & 69.0 & 8.29 & 0.207 & 0.247 & 19.21 \\
\hline LP 1 & 99.0 & 2.35 & 93.2 & 71.2 & 8.85 & 0.180 & 0.180 & 21.94 \\
\hline LP 2 & 97.0 & 2.32 & 129.7 & 71.3 & 8.84 & 0.223 & 0.227 & 20.14 \\
\hline Mavka & 122.0 & 2.61 & 130.1 & 68.7 & 7.69 & 0.227 & 0.247 & 16.70 \\
\hline Merlin & 111.8 & 2.74 & 118.0 & 65.9 & 8.14 & 0.193 & 0.207 & 27.31 \\
\hline Progres & 98.0 & 2.29 & 110.1 & 72.0 & 8.64 & 0.200 & 0.207 & 18.26 \\
\hline \multicolumn{9}{|c|}{ Growing season 2014} \\
\hline Aldana & 123.5 & 3.79 & 209.9 & 73.4 & 6.12 & 0.307 & 0.307 & 22.40 \\
\hline Annushka & 127.3 & 3.20 & 159.3 & 72.1 & 6.77 & 0.240 & 0.247 & 27.10 \\
\hline Augusta & 123.8 & 3.23 & 151.9 & 74.8 & 7.28 & 0.256 & 0.273 & 26.07 \\
\hline Jutro & 123.3 & 3.70 & 199.8 & 74.3 & 6.16 & 0.300 & 0.327 & 22.63 \\
\hline LP 1 & 121.0 & 3.20 & 159.9 & 73.0 & 7.27 & 0.267 & 0.260 & 26.20 \\
\hline LP 2 & 121.3 & 3.09 & 193.1 & 73.7 & 6.77 & 0.287 & 0.280 & 25.57 \\
\hline Mavka & 141.0 & 3.63 & 217.2 & 72.2 & 5.87 & 0.300 & 0.313 & 25.07 \\
\hline Merlin & 144.5 & 4.03 & 187.1 & 72.3 & 6.30 & 0.277 & 0.287 & 37.50 \\
\hline Progres & 121.0 & 3.33 & 173.6 & 76.5 & 6.58 & 0.260 & 0.253 & 24.10 \\
\hline \multicolumn{9}{|c|}{ Mean value for growing season } \\
\hline 2013 & 102,7 & 2.42 & 112.8 & 69.88 & 8.55 & 0.199 & 0.197 & 21.42 \\
\hline 2014 & 127.4 & 3.47 & 183.5 & 73.59 & 6.56 & 0.277 & 0.283 & 26.29 \\
\hline HSD for $Y$ & 1.80 & 0.13 & 0.63 & 0.29 & 0.15 & 0.004 & 0.012 & 0.54 \\
\hline \multicolumn{9}{|c|}{ Average across two growing seasons } \\
\hline Aldana & 111.5 & 3.17 & 165.3 & 72.4 & 7.12 & 0.267 & 0.247 & 20.10 \\
\hline Annushka & 113.4 & 2.73 & 129.0 & 70.9 & 7.88 & 0.208 & 0.193 & 28.73 \\
\hline Augusta & 111.4 & 2.71 & 123.3 & 72.2 & 8.33 & 0.207 & 0.203 & 23.55 \\
\hline Jutro & 110.9 & 3.09 & 159.9 & 71.6 & 7.22 & 0.253 & 0.287 & 20.92 \\
\hline LP 1 & 110.0 & 2.77 & 126.6 & 72.1 & 8.06 & 0.223 & 0.220 & 24.07 \\
\hline LP 2 & 109.1 & 2.70 & 161.4 & 72.5 & 7.80 & 0.255 & 0.253 & 22.86 \\
\hline Mavka & 131.5 & 3.12 & 173.7 & 70.4 & 6.78 & 0.263 & 0.280 & 20.89 \\
\hline Merlin & 128.1 & 3.39 & 152.6 & 69.1 & 7.22 & 0.235 & 0.247 & 32.40 \\
\hline Progres & 109.5 & 2.81 & 141.9 & 74.2 & 7.58 & 0.230 & 0.230 & 21.18 \\
\hline Mean value & 115.0 & 2.94 & 148.2 & 71.7 & 7.56 & 0.24 & 0.24 & 23.86 \\
\hline$C V(\%)$ & 7.4 & 8.5 & 12.6 & 2.0 & 6.7 & 9.6 & 13.3 & 17.3 \\
\hline HSD for $\mathbf{G}$ & 6.30 & 0.43 & 2.23 & 1.10 & 0.53 & 0.02 & 0.041 & 1.87 \\
\hline HSD for $\mathbf{G} \times \mathbf{Y}$ & ns & ns & 0.61 & 0.28 & ns & 0.005 & 0.014 & 0.67 \\
\hline
\end{tabular}

$C V$ - coefficient of variation; HSD - high significant difference, ns - not significant; $Y$ - year, G-genotype, Gx $Y$ - interaction 
Table 3

Tabela 3

Content of nutrients, trypsin inhibitor and phenolic components in nine soybean genotypes across two growing seasons (on DM)

Zawartość składników pokarmowych, inhibitora trypsyny i składników fenolowych w dziewięciu genotypach soi w dwóch sezonach wegetacyjnych (w s.m.)

\begin{tabular}{|c|c|c|c|c|c|c|c|}
\hline Variety & $\begin{array}{c}\text { Protein } \\
(\%)\end{array}$ & $\begin{array}{l}\text { Lipids } \\
(\%)\end{array}$ & $\begin{array}{l}\text { Ash } \\
(\%)\end{array}$ & $\begin{array}{l}\text { Starch } \\
(\%)\end{array}$ & $\begin{array}{l}\text { Trypsin } \\
\text { inhibitor }\end{array}$ & $\begin{array}{l}\text { Total } \\
\text { phenolic } \\
\text { compo- } \\
\text { nents }\end{array}$ & Tannins \\
\hline \multicolumn{8}{|c|}{ Growing season 2013} \\
\hline Aldana & 28.4 & 29.3 & 7.10 & 2.47 & 54.8 & 2.82 & 0.02 \\
\hline Annushka & 29.1 & 25.7 & 7.09 & 1.83 & 51.9 & 2.14 & 0.02 \\
\hline Augusta & 27.7 & 26.4 & 7.33 & 1.10 & 67.9 & 2.49 & 0.02 \\
\hline Jutro & 28.8 & 27.9 & 6.78 & 2.63 & 58.4 & 2.68 & 0.03 \\
\hline LP 1 & 28.6 & 26.1 & 7.22 & 1.19 & 64.7 & 2.81 & 0.08 \\
\hline LP 2 & 28.0 & 25.8 & 7.25 & 1.69 & 51.0 & 2.50 & 0.06 \\
\hline Mavka & 27.2 & 29.0 & 6.96 & 1.72 & 48.5 & 2.27 & 0.05 \\
\hline Merlin & 28.4 & 29.9 & 6.54 & 2.98 & 49.1 & 2.60 & 0.02 \\
\hline Progres & 28.5 & 28.1 & 7.17 & 1.51 & 60.5 & 2.32 & 0.01 \\
\hline \multicolumn{8}{|c|}{ Growing season 2014} \\
\hline Aldana & 37.3 & 23.7 & 6.14 & 1.86 & 43.5 & 2.88 & 0.21 \\
\hline Annushka & 35.1 & 26.1 & 6.10 & 1.67 & 39.0 & 2.62 & 0.13 \\
\hline Augusta & 36.0 & 24.6 & 6.60 & 1.35 & 51.2 & 2.88 & 0.07 \\
\hline Jutro & 36.8 & 25.1 & 6.20 & 1.95 & 51.1 & 2.87 & 0.07 \\
\hline LP 1 & 37.2 & 23.7 & 6.45 & 1.18 & 52.0 & 2.85 & 0.07 \\
\hline LP 2 & 36.8 & 24.4 & 6.28 & 1.06 & 53.5 & 2.79 & 0.09 \\
\hline Mavka & 36.5 & 24.6 & 5.81 & 1.64 & 41.9 & 2.53 & 0.10 \\
\hline Merlin & 36.1 & 25.8 & 5.47 & 1.96 & 43.8 & 3.17 & 0.10 \\
\hline Progres & 37.0 & 23.7 & 6.36 & 1.04 & 49.7 & 2.79 & 0.05 \\
\hline \multicolumn{8}{|c|}{ Mean value for growing season } \\
\hline 2013 & 28.3 & 27.6 & 7.05 & 1.90 & 56.3 & 2.51 & 0.035 \\
\hline 2014 & 36.5 & 24.6 & 6.16 & 1.52 & 47.3 & 2.67 & 0.097 \\
\hline HSD for $Y$ & 0.14 & 0.16 & 0.02 & 0.02 & 0.27 & 0.03 & 0.003 \\
\hline \multicolumn{8}{|c|}{ Average across two growing seasons } \\
\hline Aldana & 32.8 & 26.5 & 6.62 & 2.16 & 49.1 & 2.85 & 0.12 \\
\hline Annushka & 32.1 & 25.9 & 6.60 & 1.75 & 45.4 & 2.38 & 0.07 \\
\hline Augusta & 31.9 & 25.5 & 6.96 & 1.23 & 59.5 & 2.69 & 0.05 \\
\hline Jutro & 32.8 & 26.5 & 6.49 & 2.29 & 54.7 & 2.77 & 0.05 \\
\hline LP 1 & 32.9 & 24.9 & 6.84 & 1.18 & 58.3 & 2.83 & 0.07 \\
\hline LP 2 & 32.4 & 25.1 & 6.77 & 1.38 & 52.2 & 2.65 & 0.08 \\
\hline Mavka & 31.8 & 26.8 & 6.39 & 1.68 & 45.2 & 2.40 & 0.07 \\
\hline Merlin & 32.2 & 27.9 & 6.00 & 2.47 & 46.4 & 2.88 & 0.06 \\
\hline Progres & 32.8 & 25.9 & 6.76 & 1.28 & 55.1 & 2.56 & 0.03 \\
\hline Mean value & 32.4 & 26.1 & 6.60 & 1.71 & 51.8 & 2.67 & 0.07 \\
\hline $\mathrm{CV}, \%$ & 1.3 & 3.5 & 4.3 & 28.7 & 10.6 & 7.1 & 36.0 \\
\hline HSD for $G$ & 0.49 & 0.57 & 0.07 & 0.08 & 0.97 & 0.10 & 0.01 \\
\hline HSD for $\mathbf{G} \times \mathbf{Y}$ & 0.132 & 0.157 & 0.018 & 0.020 & 0.266 & 0.028 & 0.002 \\
\hline
\end{tabular}

Trypsin inhibitor expressed as TIU $\cdot g^{-1} D M$; Total phenolic components expressed in $\mathrm{mg}$ of gallic acid equivalent per $\mathrm{g}(\mathrm{mg}$ $\left.G A E \cdot g^{-1} D M\right)$; Condensed tannin content was expressed as $m g$ of catechin equivalents per $g$ DM sample $\left(\mathrm{mg} C E \cdot \mathrm{g}^{-1} \mathrm{DM}\right)$; $C V$-coefficient of variation; HSD - high significant difference; $Y$-year, $G$-genotype, G x $Y$-interaction. 
Table 4

Tabela 4

Content of total dietary fibre and its individual constituents (DM \%) in nine genotypes across two growing seasons

Zawartość włókna pokarmowego ogółem i jego poszczególnych składników (\% s.m.) w dziewięciu genotypach soi dwóch sezonach wegetacyjnych

\begin{tabular}{|c|c|c|c|c|c|c|c|}
\hline Variety & $\begin{array}{c}\text { Insoluble } \\
\text { nonstarch } \\
\text { polysaccharides }\end{array}$ & $\begin{array}{c}\text { Soluble } \\
\text { nonstarch } \\
\text { polysaccharides }\end{array}$ & $\begin{array}{l}\text { Total nonstarch } \\
\text { polysaccharides }\end{array}$ & $\begin{array}{l}\text { Raffinose family } \\
\text { oligosaccharides }\end{array}$ & $\begin{array}{l}\text { Total uronic } \\
\text { acid }\end{array}$ & Lignin & $\begin{array}{c}\text { Total dietary } \\
\text { fibre }\end{array}$ \\
\hline \multicolumn{8}{|c|}{ Growing season 2013} \\
\hline Aldana & 11.15 & 0.89 & 12.04 & 6.47 & 3.84 & 2.63 & 24.98 \\
\hline Annushka & 10.70 & 0.88 & 11.58 & 7.29 & 3.34 & 2.29 & 24.50 \\
\hline Augusta & 9.88 & 0.85 & 10.73 & 7.77 & 3.56 & 2.34 & 24.40 \\
\hline Jutro & 9.72 & 0.81 & 10.53 & 7.81 & 3.42 & 2.06 & 23.81 \\
\hline LP 1 & 10.92 & 0.76 & 11.69 & 8.42 & 3.60 & 2.15 & 25.86 \\
\hline LP 2 & 10.41 & 0.80 & 11.22 & 7.94 & 3.42 & 1.49 & 24.07 \\
\hline Mavka & 10.36 & 0.85 & 11.21 & 7.59 & 3.49 & 2.43 & 24.72 \\
\hline Merlin & 10.05 & 0.82 & 10.88 & 7.10 & 3.61 & 1.87 & 23.46 \\
\hline Progres & 11.42 & 0.83 & 12.26 & 7.37 & 3.97 & 2.21 & 25.81 \\
\hline \multicolumn{8}{|c|}{ Growing season 2014} \\
\hline Aldana & 11.06 & 0.72 & 11.77 & 6.48 & 2.82 & 2.75 & 23.82 \\
\hline Annushka & 11.73 & 0.62 & 12.35 & 6.01 & 2.84 & 1.46 & 22.67 \\
\hline Augusta & 11.98 & 0.69 & 12.68 & 6.66 & 3.15 & 1.67 & 24.16 \\
\hline Jutro & 10.95 & 0.67 & 11.63 & 5.44 & 2.75 & 1.68 & 21.49 \\
\hline LP 1 & 12.41 & 0.62 & 13.03 & 5.85 & 3.13 & 1.23 & 23.25 \\
\hline LP 2 & 12.84 & 0.70 & 13.53 & 5.35 & 2.79 & 1.26 & 22.94 \\
\hline Mavka & 11.77 & 0.72 & 12.49 & 5.37 & 3.01 & 1.35 & 22.21 \\
\hline Merlin & 10.95 & 0.64 & 11.59 & 6.31 & 2.75 & 2.38 & 23.03 \\
\hline Progres & 11.79 & 0.63 & 12.42 & 6.79 & 3.35 & 1.44 & 24.00 \\
\hline \multicolumn{8}{|c|}{ Mean value for growing season } \\
\hline 2013 & 10.51 & 0.83 & 11.35 & 7.53 & 3.59 & 2.16 & 24.63 \\
\hline 2014 & 11.72 & 0.67 & 12.39 & 6.03 & 2.96 & 1.69 & 23.07 \\
\hline HSD for $Y$ & 0.18 & $\mathbf{0 . 0 3}$ & 0.18 & 0.13 & 0.04 & $\mathbf{0 . 0 3}$ & 0.25 \\
\hline \multicolumn{8}{|c|}{ Average across two growing seasons } \\
\hline Aldana & 11.10 & 0.81 & 11.91 & 6.48 & 3.33 & 2.69 & 24.41 \\
\hline Annushka & 11.21 & 0.75 & 11.96 & 6.65 & 3.10 & 1.88 & 23.59 \\
\hline Augusta & 10.93 & 0.77 & 11.70 & 7.22 & 3.36 & 2.01 & 24.29 \\
\hline Jutro & 10.34 & 0.74 & 11.08 & 6.63 & 3.08 & 1.87 & 22.66 \\
\hline LP 1 & 11.67 & 0.70 & 12.37 & 7.14 & 3.37 & 1.69 & 24.56 \\
\hline LP 2 & 11.63 & 0.75 & 12.38 & 6.65 & 3.11 & 1.38 & 23.52 \\
\hline Mavka & 11.63 & 0.78 & 12.41 & 6.48 & 3.25 & 1.89 & 23.47 \\
\hline Merlin & 10.05 & 0.73 & 10.78 & 6.71 & 3.18 & 2.13 & 23.25 \\
\hline Progres & 11.61 & 0.73 & 12.34 & 7.08 & 3.67 & 1.82 & 24.91 \\
\hline Mean value & 11.12 & 0.75 & 11.87 & 6.78 & 3.27 & 1.93 & 23.85 \\
\hline $\mathrm{CV}, \%$ & 4.1 & 4.2 & 3.8 & 4.0 & 5.4 & 17.3 & 2.9 \\
\hline HSD for $G$ & 0.63 & 0.09 & 0.65 & 0.45 & 0.14 & 0.09 & 0.89 \\
\hline HSD for $\mathbf{G} \times \mathbf{Y}$ & 0.172 & ns & 0.176 & 0.122 & 0.038 & 0.026 & 0.243 \\
\hline
\end{tabular}

$C V$ - coefficient of variation; HSD - high significant difference; $Y$ - year, G-genotype, Gx $Y$ - interaction; ns - not significant 
in soy- bean seed from adverse weather conditions of 2013 growing season supports findings about their role in protecting plant against abiotic stress (ElSayed et al. 2014).

\section{Effect of variety on physicochemical characteri- stics}

Regarding physical seed characteristics, soybean varieties were most differentiated in CT $(\mathrm{CV} \%=17.3)$, then in $\mathrm{SC}(\mathrm{CV} \%=13.3)$ and $\mathrm{TSW}$ $(\mathrm{CV} \%=12.6)$. The variability of the other physical characteristics was below $10 \%$ (Table 2). Under the given experimental conditions, the Merlin variety yielded highest in each year (2.74 and 4.03 tha respectively), giving an average seed yield over the two years of 3.4 tha. Slightly lower seed yields were shown for the varieties Aldana, Mavka and Jutro, ranging from 3.17-3.09 tha, with insignificant differences between varieties. Among the best yielding varieties, only Merlin and Mavka belonged to the semi-late maturity group. The lowest-yielding varieties were varieties belonging to early and very early group of earliness, such as two breeding lines LP1 and LP2 and varieties Annushka, Augusta and Progress. The same ranking of varieties in terms of yielding was in each year of the study.

High variation among varieties was found in the content of bioactive components, such as tannins $(\mathrm{CV} \%=36)$ and trypsin inhibitor $(\mathrm{CV} \%=10.6)$ and also nutrients such as starch $(\mathrm{CV} \%=28.7)$. For other seed physical characteristics and nutrient contents, soybean varieties showed little variation, in the range from $7.1 \%$ to $1.3 \%$ for content of total phenolic components and protein, respectively (Table 3). Although little varietal variability was shown, early maturing varieties like Aldana, Jutro, LP1 and Progres had significantly more protein $(32.8-32.9 \%)$ than the other varieties (31.8-32.4\%).

The dietary fiber (DF) is the sum of the nonstarch polysaccharides, oligosaccharides, uronic acids and lignin. Depending on its solubility in water, TDF is further divided into insoluble and soluble fractions. Each component of TDF is resistant to digestion and absorption in the small intestine with complete or partial fermentation in the large intestine (AACC Report, 2001). Dietary fibre showed several physiological effects that are beneficial to health, summarised recently by Barber et al. (2020). In present study, the coefficient of variation for the content of TDF as well as its main components within varieties was small $(\mathrm{CV}=2.9 \%$ to $\mathrm{CV}=5.4 \%)$. Only lignin content showed high variability at $\mathrm{CV}=17.3 \%$ (Table 4). TDF content ranged from $22.7 \%$ to $24.9 \%$, I-NSP from $10.5 \%$ to $11.7 \%$ and S-NSP from $0.70 \%$ to $0.81 \%$. The Progres variety had the most TDF $(24.9 \%)$, as well as uronic acids (3.7\%). This variety, along with Mavka, LP1 and LP2, was in the group of varieties with the highest amount of I-NSP (12.3-12.4\%). The contents of TDF in our study correspond well with the results reported by Medic et al. (2014) for raw seed of soybean genotypes. Soya beans are a good source of dietary fibre in our diet. In Asian countries soybean seeds are consumed on a mass scale, in Poland more and more people discover their advantages. However, the high content of dietary fibre in the feed mixture negatively affects the growth performance parameters of monogastric animals. The addition of feed enzymes, including endoxylanases, is commonly used strategy to eliminate the undesirable effect of high inclusion of dietary fibre in the feed mixture. Moreover, the formation of arabinoxylan oligosaccharides in the gut, as a result of xylanases, contributes to animal welfare through their prebiotic effects (Damen et al. 2012).

The significant impacts of genotype, environment and their interaction on seed RFOs concentrations have been reported in soybean (Kumar et al., 2010). The correlation analysis, as expected, revealed that RFOs in seed was significantly positively correlated with percent of seed coat $(\mathrm{r}=0.77)$, with TUI $(\mathrm{r}=0.81)$ and TDF $(r=0.62)$ and negatively with TSW $(\mathrm{r}=-0.82)$ and starch $(\mathrm{r}=-0.68)$.

In many technological processes of soybean, the starting points is hydration followed by cooking to improve the aroma, thereby, improving the taste and texture of seeds for consumption (Destero et al. 2013). Cooking also increases nutritional value, inactivating antinutritional factors, and, consequently, improving nutrients digestion. By reducing cooking time, energy and meal preparation time are also saved (Destero et.al. 2013). Hydration capacity varied between genotypes from 0.207 to $0.267 \mathrm{~g} \cdot \mathrm{seed}^{-1}$ with an average of $0.24 \mathrm{~g} \cdot \mathrm{seed}^{-}$ 1, while swelling capacity 0.193 to 0.287 $\mathrm{ml} \cdot$ seed $^{-1}$ (Table 2). Our results related to hydration capacity, and swelling capacity are within the range reported by Sridhara et al. (1997) and higher than that Goyal et al. (2015) as a result of much lower TSW of soybean varieties used in their studies. Accessions with higher seed weight had higher hydration and swelling capacity. It has recently been shown that knowledge of the physical characteristics of soybean is not only useful for the use 
of the seed for food purposes, but also as a predictive parameter in feed formulation. Such a parameter is hydration capacity, as it seems to affect the transit time of ingesta, organ development (such as birds crop and gizzard), feed intake and satiety feeling (Brachet et al., 2015).

The thousand seed weight, bulk density, water absorption and cooking time traits are important characteristics of soybean seed destined for canning industry and home preparation and uses. Cooking time revealed significant differences among tested accessions varied from 20.1 to 32.4 min with average of $23.9 \mathrm{~min}$. Average cooking time for soybean seed were longer than average cooking time reported earlier for common bean (Boros and Wawer, 2018) or pea (Wang et al. 2010). There are several reports on cooking time of soybean seeds but direct comparison of our results is not possible since different cooking methods were used (Sridhara et al. 1997; Sharma et al. 2004; da Silva et al. 2009; Destero at al. 2013). Cooking time was negatively correlated with seed bulk density $(r=-0.67)$ and with hydration capacity $(\mathrm{r}=-0.52)$ as well with ash content $(\mathrm{r}=-0.52)$. Among tested genotypes four were fast cooking (Aldana, Progres, Jutro, Mavka), which may be effective for reducing processing cost, whereas two (Merlin and Annushka) were hard to cook. This information would be useful for breeders and geneticists in order to use source of tested genotypes to widen genetic base of currently cultivated soybean varieties.
Seed coat and closely correlated ash content $(\mathrm{r}=0.72)$ were in the range shown by Staniak et al. (2021). Average content of TPC in soybean seeds in our study was consistent with the range reported by other authors (Xu et al. 2007) while content of tannin (TA) in seeds lower than that of Singh et al. (2017). Similarly average content of seed starch in our study was higher than reported earlier (Medic et al. 2014).

The principal components analysis was used to limit the number of primary variables, to describe the total variation of a population and to explain the traits contribution to total variation (Figure 3). In the principal components analysis, five eigenvalues were higher than one, explaining 91.5\% of the variance in the data set of 21 original variables (in analysis a total content of NSP was omitted, as it constitutes a sum of INSP and SNSP). Eigenvalues above one (1.0) generate components with significant quantities of information of the original variables. The eigenvalue for the first principal component (PC1) was 9.19, which corresponds to $43.77 \%$ of total variance. The eigenvalue for the second main component (PC2) was 3.75, which retained $17.86 \%$ of the total variance, the third main component (PC3) retained $14.03 \%$ of the variance fourth $9.5 \%$ and fifth $4.7 \%$ of the variance respectively. For each principal component some traits are positively and some negatively correlated. For PC1 traits vector to the right and for $\mathrm{PC} 2$ vectors above axis indicates positive correlations. The angle between

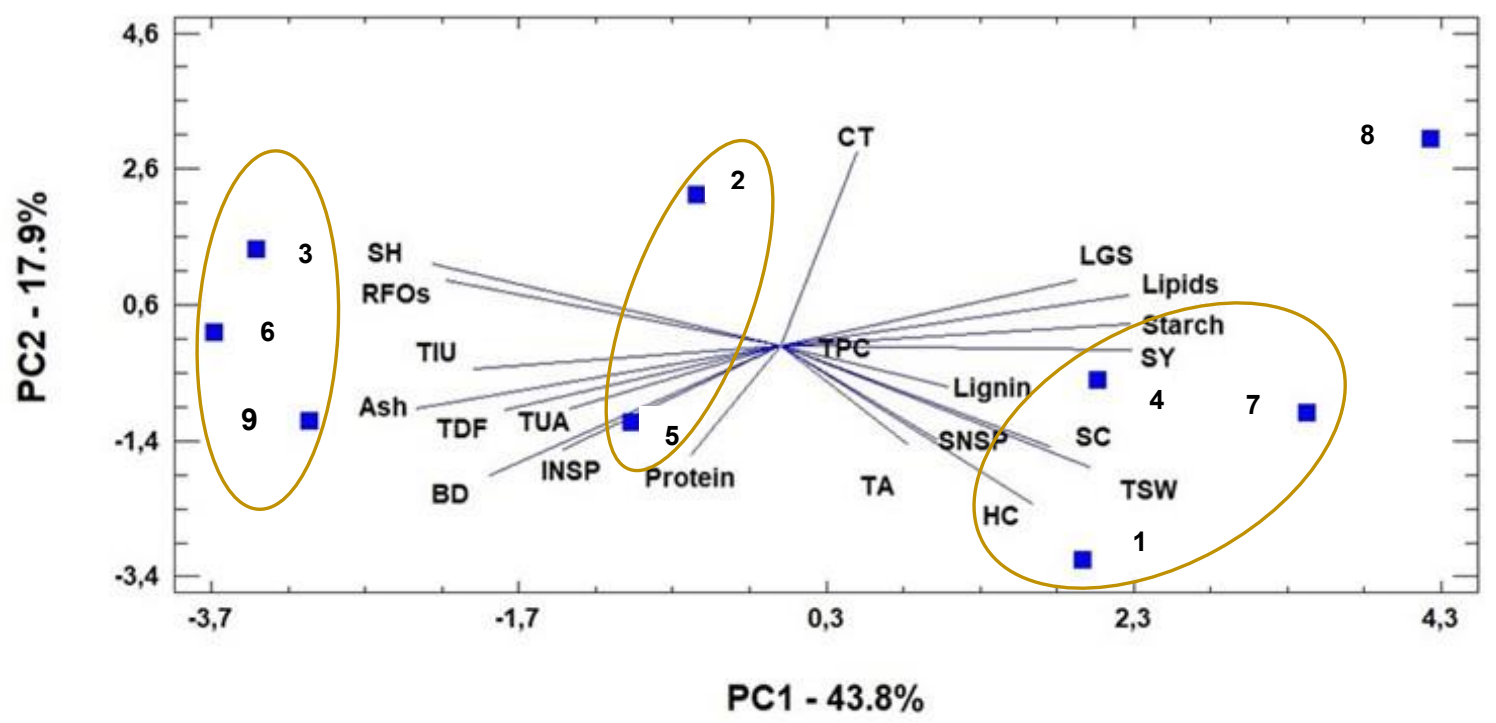

Figure 3. Biplot displaying eigenvectors and scores for first two principal components

Rysunek 3. Biplot przedstawiający wektory własne i wartości dla dwóch pierwszych składowych głównych Footnote: numbers were assigned to genotypes as follows: 1. Aldana, 2. Annuszka, 3.Augusta, 4. Jutro, 5. LP1, 6. LP2, 7. Mawka, 8. Merlin, and 9. Progres. Abbreviations for trait vectors refer to abbreviations given in Table 1. 
the vectors is an approximation of the correlation between the variables. Traits vector on biplot with small angle indicates that variables are positively correlated with each other, an angle of 90 degrees indicates the variables are not correlated, and an angle close to 180 degrees indicates the variables are negatively correlated. The dispersion of soybean varieties on biplot for first two principal components allowed to identified four groups. The first group of three genotypes (Augusta, LP-2 and Progres) are early maturing varieties with lower seed yield, the highest bulk density, high seed coat and ash content. The next group of two soybean varieties (Annushka and LP-1) differed from the first group mainly by the lowest TSW. The third group of soybean varieties (early maturing Aldana, Jutro and late maturing Mavka) placed in the lower right part of the graph, was characterised by high seed yield, highest TSW, highest hydration and swelling capacity and short cooking time. The highest-yielding, late-maturing variety Merlin differed from the previous group primarily in having higher starch and total phenolic contents and the longest cooking time among the varieties tested.

\section{Conclusion}

A highly significant effect of genotype and harvest year on the evaluated soybean seed traits was found. Moreover, except for the length of growing season, seed yield, content of seed coat and non-starch polysaccharides, a significant genotype $\mathrm{x}$ year interaction was observed for the remaining traits. The significance of $\mathrm{G} \times \mathrm{Y}$ interaction indicates differences in the response of the tested soybean genotypes to given weather conditions. However, G x Y interaction contributed only a small proportion of the total variation of the trait. Soybean genotypes represented a fairly wide range of variability for most traits. Knowledge of these traits and their variability among varieties and breeding lines is important to plant breeders, food scientist, technologists and consumers. Some of soybean varieties tested have proven to be particularly interesting sources of genetic variation for traits such as earliness, seed yield potential and shorter cooking time. These may be available to breeders seeking to develop varieties that meet the expectations of end-users. Among several quality traits in need of improvement, reducing cooking time comes to the forefront, which would likely influence more frequent use of soybeans in the human daily diet. Cooking is essential to improve the taste of soybeans, thereby improving their aroma and texture for consumers.

\section{Acknowledgements}

This research has been founded by CORNET, in frame of ProLegu project, through the Polish National Centre for Research and Development (NCBR/CORNET-15/2012/2013).

\section{References}

AACC Report (American Association of Cereal Chemists). (2001). The definition of dietary fiber. Cereal Food World, 46 (3), 112-126.

AOAC (Association of Official Analytical Chemists). Official Methods of Analysis, AOAC International, 18th ed. Gaithersburg, MD, USA. (2010). Methods: 934.01 (dry matter); 955.04 (protein); 923.03 (ash) and 996.11 (starch available); 994.13 (dietary fibre).

Assefa, Y., Purcell, L.C., Salmeron, M., Neave, S.., Casteel, S.N., Kovac, P., Archontoulis, S., Licht, M., Below, F., Kancel, H., Lindsey, L.E., Gaska, J., Conley, S., Shapiro, C., Orlowski, J.M., Golden, B.R., Kaur, G., Singh, M., Thelen, K., Laurenz, R., Davidson, D., Ciampatti, I.A. (2019). Assessing variation in US soybean seed composition (protein and oil). Front. Plant Sci.. 10, 1-13, doi: 10.3389/fpls.2019.00298,

Banaszkiewicz, T. (2011). Nutritional value of soybean meal. In: El-Shemy H.A. (Ed.), Soybean and Nutrition, InTech.

Barber, T. M., Kabisch, S., Pfeiffer, A., \& Weickert, M. O. (2020). The health benefits of dietary fibre. Nutrients, 12 (10), 3209, doi.org/10.3390/nu12103209.

Bellaloui, N., Bruns, H.A., Abbas, H.K., Mengistu, A., Fisher, D.K., Reddy, K.N. (2015) Effects of row-type, row-spacing, seeding rate, soil-type, and cultivar differences on soybean seed nutrition under US Mississippi delta conditions. PLoS ONE, 10 (6) e 0129913, doi.org/10.1371/ journal.pone.0129913.

Boros, L., Wawer, A. (2018). Seeds quality characteristics of dry bean local populations (Phaseolus vulgaris L.) from National Center for Plant Genetic Resources in Radzikow"; Legum. Res., 41 (5), 669-674.

Brachet, M., Arroyo, J., Bannelier C., Cazals, A. (2015). Hydration capacity: A new criterion for feed formulation. Anim. Feed Sci. Technol., 209, 174-185.

COBORU (2020). https://coboru.gov.pl/Publikacje_ COBORU/IB/Informator_2020.pdf

COBORU (2021). Wyniki porejestrowych doświadczeń odmianowych. Bobowate grubonasienne i soja 2020. No 163, COBO 42/2021 n.330.

Damen, B., Pollet, A., Dornez, E. Broekaert, W.F., Van Haesendonck, I., Trogh, I., Arnaut, F., Delcour, J.A. (2012). Xylanase-mediated in situ production of arabinoxylan oligosaccharides with prebiotic potential in whole meal breads and breads enriched with arabinoxylan rich materials. Food Chem., 131 (1), 111-118, doi: 10.1016/j. 
foodchem.2011.08.043

da Silva, J.B., Carráo-Panizzi, M.C., Prudêncio, S.H. (2009). Chemical and physical composition of grain-type and food -type soybean for food processing. Pesq. agropec. bras, Brasilia, 44 (7), 777-784.

Destro, D., Faria, A.., Destro, T.M., Faria, R., Gonçalves, L.S.A., Lima, W.F. (2013). Food type soybean cooking time: a review. Crop Breed. Appl. Biotechnol., 13, 194-199, doi.org/10.1590/S1984-70332013000300007.

ElSayed, A.I., Rafudeen, M.S., Golldack, D. (2014). Physiological aspects of raffinose family oligosaccharides in plants: protection against abiotic stress. Plant Biol., $16,1-8$.

Englyst, H.N., Cummings, J.H. (1984). Simplified method for the measurement of total non-starch polysaccharides by gas-liquid chromatography of constituent sugars as alditol acetates. Analyst., 109, 937-942.

EFSA, European Food Safety Authority (2010). Scientific opinion on dietary reference values for carbohydrates and dietary fibre. EFSA Journal, 8, 1508-1569, doi. org/10.2903/j.efsa.2010.1462.

FAOSTAT (2020). Food and Agriculture Organization of the United Nations. Rome. http://faostat.fao.org.

Goyal, R., Sharma, S., Gill, B.S. (2015). Effects of location and planting time on physicochemical and nutritional characteristics of soybean seed. Legum. Res., 38, 810-815, doi: 10.18805/lr.v38i6.6728.

Huber, S.C., Li K., Nelson, R., Ulanov, A., DeMuro, C.M., Baxter, I. (2016). Canopy positions has profound effect on soybean seed composition. Peer J., 4, e2452, doi: 10.7717/peerj. 2452.

Jha, R., Fouhse, J.M., Tiwari, U.P., Li, L., Willing, P.W. (2019). Dietary fiber and intestinal health of monogastric animals. Front. Vet. Sci., 6, 48, doi.org/10.3389/fvets.2019.00048.

Kakade, M.L, Rackis, J.E., McGhee, Puski, G. (1974). Determinantion of trypsin inhibitor activity of soy products: A collaborative analysis of an improved procedure. Cereal Chem., 51, 376-382.

Kumar, V, Rani, A, Goyal, L, Dixit, AK, Manjaya, J, Dev, J, Swamy, M. (2010) Sucrose and raffinose family oligosaccharides (RFOs) in soybean seeds as influenced by genotype and growing location. J. Agric. Food Chem., 58, 5081-5085, doi: 10.1021/jf903141s.

Lahuta, L.B. (2006). Biosynthesis of raffinose family oligosaccharides and galactosyl pinitols in developing and maturing seeds of winter vetch (Vicia villosa Roth.). Acta Soc. Bot. Pol., 75 (3), 219-227.

Li, M., Liu, Y., Wang, C., Yang, X., Li, D., Zhang X., Xu, C., Zhang, Y., Li, W., Zhao, L. (2020). Identification of traits contributing to high and stable yields in different soybean varieties across three Chinese latitudes. Front. Plant Sci., 10, no. 1642. doi.org/10.3389/fpls.2019.01642

Liener, I.E. (1994). Implications of antinutritional components in soya bean feeds. Crit. Rev. Food Sci. Nutr., 34 (1),
31-67.

Marchello, J.A., Dryden, F.D., Hale, W.H. (1971). Bovine serum lipids. I. The influence of added animal fat on the ration. J. Anim. Sci., 32, 1008-1015.

Martinez-Villaluenga, C., Zieliński, H., Frias, J., Piskuła, M. K., Kozłowska, H., Vidal-Valverde, C. (2009). Antioxidant capacity and polyphenolic content of high -protein lupin products. Food Chem., 112, 84-88.

Medic, J., Atkinson, Ch., Hurburgh, Ch.R.Jr. (2014). Current knowledge in soybean composition. J. Am. Oil Chem. Soc., 91, 363-384.

Mourtzinis, S., Kaur, G., Orlowski, J. M., Shapiro, C. A., Lee, C. D., Wortmann, C., Holshousere D., Nafzigerf E.D., Kandelg, H., Niekampf, J., Rossh, W.J., Loftoni, J., Vonkf, J., Roozeboomj, K.L., Thelenk, K.D., Lindseyl, L.E., Statonm, M., Naeven, S.L., Casteelo, S.N., Wieboldp, W.J., Conley, S.P. (2018). Soybean response to nitrogen application across the United States: A synthesis-analysis. Field Crops Res., 215, 74-82, doi.org/10.1016/j. fcr.2017.09.035.

NRC (2012). National Research Council. Nutrient Requirements of swine. $11^{\text {th }}$ rev. ed. Natl. Acad. Press, Washington DC. doi.org/10.17226/13298.

O‘Bryan, C.A., Kushwaha, K., Babu, D., Crandall, P.G., Davis, M., Chen, P., Lee, S-O., Ricke, S.T. (2014). Soybean seed coats: A source of ingredients for potential human health benefits. A review of the literature. J. Food Res., 3 (6), 188-201, doi: 10.5539/jfr.v3n6p188.

Price, M.L., Van Scoyoc, S., Butler, L.G. (1978). A critical evaluation of the vanillin reaction as an assay for tannin in sorghum grain. J. Agric. Food Chem., 26, 1214-1218.

Xu, B.J., Yuan, S.H., Chang, S.K.C. (2007). Comparative analyses of phenolic composition, antioxidant capacity, and color of cool season legumes and other selected food legumes. J. Food Sci., 72 (2), S167- 177.

Saldivar, X., Wang, Y-J., Chen,.P, Hou, A. (2011). Changes in chemical composition during soybean seed development. Food Chem., 124 (4), 1369-1375. doi.org/10.1016/j. foodchem.2010.07.091.

Scheppach, W., Luehrs, H., Melcher, R., Gostner, J. Schauber, T. Kudlich, F. Weiler, T., Menzel, T. (2004). Antiinflammatory and anticarcinogenic effects of dietary fibre. Clin. Nutr. Suppl., 1 (2), 51-58.

Scott, R.W. (1979). Colorimetric determination of hexouronic acids in plant materials. Analyt. Chem., 51, 936-941.

Sharma, S., Saxena, A.K., Dhillon, S.K. (2004). Physicochemical and cooking quality characteristics of soybean (Glycine max). J. Food Sci. Technol.-Mysore., 41, 554-556.

Singh, B., Singh, J.P., Kaur, A., Singh, N. (2017). Phenolic composition and antioxidant potential of grain legume seeds: A review. Food Res. J., 101, 1-16, doi. org/10.1016/j.foodres.2017.09.026.

Sridhara, S., Thimmegowda S., Chalapathi M.V. (1997). 
Nutritional values, physical and physico-chemical characteristics and cooking quality of soybean (Glycine max (L) Merr.) genotypes. Crop Res., 13 (2), 259-266.

Staniak, M., Stępien-Warda, A., Czopek, K., Kocira, A., Baca, E. (2021). Seed quality and quantity of soybean [Glycine $\max ($ L.) Merr] cultivars in response to cold stress. Agronomy, 11, 520, doi.org/10.3390/agronomy11030520.

Theander, O., Åman, P., Westerlund, E., Andersson, R., Pettersson, D. (1995). Total dietary fiber determined as neutral sugar and uronic acid residues, and lignin (The Uppsala method): Collaborative study. J. Assoc. Offic. Anal. Chem., 78, 1030-1044.

The Common Catalogue (2020). https://www.ec.europa.eu/ food/sites/food/foles/docs/plant-variety-catalogues_agricultural-plant-species.pdf
Vollmann, J., Fritz, C.N., Wagentrist, H. (2000). Environmental and genetic variation of soybean seed protein content under Central European growing conditions. J. Sci. Food Agric. 80, 1300-1306.

Wang, N., Hatcher, D.W., Warkentin, T.D., Toews, R. (2010). Effect of cultivar and environment on physicochemical and cooking characteristics of field pea (Pisum sativum). Food Chem., 118, 109-115, doi: 10.1016/j. foodchem.2009.04.082.

Wocławek, Potocka, I., Bah, M.M., Korzekwa, A., Piskula, M.K., Wiczkowski, W., Depta, A., Skarżyński, D.J. (2005). Soybean-derived phytoestrogens regulate prostaglandin secretion in endometrium during cattle estrous cycle and early pregnancy. Exp. Biol. Med., 230 (3), 189-199. 